\title{
Suicídio e trabalho: o que fazer?*
}

\section{Julia Trevisan Martins ${ }^{1}$, Renata Perfeito Ribeiro ${ }^{2}$}

Nesta obra, seus autores tecem reflexões a respeito de que no passado não ocorriam suicídios em locais de trabalho, apontando duas razões para tal fato: a primeira, relaciona-se aos ambientes laborais que eram ocupados, predominantemente, por homens e onde eram elaboradas estratégias de defesa coletiva para combater o sofrimento. As estratégias visavam, essencialmente, a mostrar coragem, resistência ou indiferença ao sofrimento para a sociedade Essa tradição forçava os indivíduos a que levassem o sofrimento para fora do labor e, por sua vez, os gestos de suicídios eram praticados em outros locais, mesmo quando a relação do homem com o trabalho fosse a causa da descompensação que o levou a cometer esse ato extremo. A segunda razão, refere que o trabalhador quando se encontrava em sofrimento, e este era percebido por seus companheiros de trabalho, surgiam sentimentos de solidariedade e de ajuda ao colega. Entretanto, nos dias atuais, o que tem se instalado no mundo do trabalho é a cultura de "cada um por si" e a solidão torna-se uma regra e provoca uma intensa degradação do conviver junto, o viver coletivo e a união. Assim, não há mais estratégias de defesa para o trabalhador e a saída encontrada é o suicídio que agora já é cometido em seu local de trabalho.

Para os autores, o trabalhador precisa ser reconhecido pelo produto de seu trabalho, pela qualidade do que foi produzido e reforçam que este reconhecimento não é relativo à pessoa. Para eles, a psicodinâmica do reconhecimento é capaz de transformar o sofrimento no trabalho em prazer, revelando a identidade do ser humano que constitui uma "armadura" para a saúde mental.

Os autores ainda expressam que a avaliação individualizada do desempenho no trabalho colabora para a concorrência entre os trabalhadores e que os resultados desta forma de avaliação provocam deslealdade, desconfiança e o comportamento de vigiar os colegas, que passam a ser considerados como adversários.

Assim, cada trabalhador se percebe só, e a solidão, o abatimento, a desesperança e o medo de ser traído por seus pares instalam-se nas organizações, tornando o ambiente de trabalho tão hostil que leva o indivíduo a cometer o gesto de suicídio.

Conforme os autores o suicídio não pode ser interpretado como um ato isolado e livre está endereçado a outro e que para vencê-lo é necessário substituir a competitividade e o isolamento, por sentimentos de cooperação e solidariedade.

Enfim, apesar do contexto focado referir-se à França, no ano de 1998, onde surgiram vários casos de suicídios no ambiente laboral, muitos pontos podem ser extrapolados para outras sociedades, e, mesmo esta bibliografia que não faz menção específica ao trabalho da saúde, em especial, à enfermagem, muitas considerações são básicas para fundamentar discussões sobre os determinantes estruturais no processo organizativo do trabalho de saúde e, particularmente, no trabalho de enfermagem, buscando formas de prevenção para o suicídio no trabalho.

\footnotetext{
* Dejours C, Bègue F. Suicídio e trabalho: o que fazer?. Brasilia: Paralelo; 2010. 128p.

${ }^{1}$ Doutora. Professora Adjunta do Curso de Graduação em Enfermagem da Universidade Estadual de Londrina - UEL - Londrina (PR), Brasil.

${ }^{2}$ Doutoranda da Escola de Enfermagem de Ribeirão Preto da Universidade de São Paulo. Professora Assistente do Curso de Graduação em Enfermagem da Universidade Estadual de Londrina - UEL - Londrina (PR), Brasil.
} 